\title{
Trade misinvoicing in copper products: a case study of Chile and Peru ${ }^{1}$
}

\author{
Michael Hanni and Andrea Podestá
}

\begin{abstract}
This study examines the underinvoicing of exports of copper concentrates and refined copper cathodes from Chile and Peru. A novel methodology, which takes the industry's standard contractual terms and insurance and freight costs into account, is used to reveal the existence of below-market unit prices in copper trading. A sharp decline since 2011 in the extent of underinvoicing reflects improvements in the area of international taxation in the two countries; however, this progress represents no more than the first steps towards the establishment of a strong enough legal framework and institutional structure for the proper oversight of mining activity in its entirety. Given the complexity of evaluating and inspecting transactions of mining products, attention is drawn to the importance of strengthening tax and customs administrations.
\end{abstract}

\section{Keywords}

Copper, copper industry, exports, prices, invoices, illegality, taxation, tax administration, case studies, Chile, Peru

\section{JEL classification}

H26, H32, Q37

\section{Authors}

Michael Hanni is an Economic Affairs Officer with the Economic Development Division of the Economic Commission for Latin America and the Caribbean (ECLAC). Email: michael.hanni@cepal.org.

Andrea Podestá is a Consultant for the Economic Development Division of the Economic Commission for Latin America and the Caribbean (ECLAC). Email: apodestae@gmail.com.

\footnotetext{
1 This article expands upon the final report of a joint project conducted by the Economic Commission for Latin America and the Caribbean (ECLAC) and Deutsche Gesellschaft für Internationale Zusammenarbeit (GIZ) entitled Illicit Financial Flows, Tax Evasion and the Extractive Sector. The project was part of the cooperation programme on combating illicit financial flows funded by the Federal Ministry for Economic Cooperation and Development (BMZ) of Germany. The authors are grateful for the comments and suggestions made by an anonymous referee.
} 


\section{Introduction}

The loss of tax revenues from the development and sale of raw materials is an issue of key importance for developing countries. The global economic slowdown and the drop in international commodity prices - and especially prices for crude oil and mineral and metals - from the levels seen during the commodity price boom have led to a steep reduction in public revenues. This situation has prompted many countries to address shortcomings in their systems for overseeing international trade in raw materials that could be costing them millions of dollars in foregone income.

Very little research on this problem has been done to date, but it is becoming of greater interest to governments and the wider public because the studies done so far have provided compelling evidence that the problem may be a very serious one indeed. For example, the Economic Commission for Africa (ECA) has found that the losses of capital occasioned by illicit financial outflows from the continent have increased significantly in the past few years and mainly take the form of misinvoiced transactions involving raw materials, especially crude oil, minerals and metals (ECA, 2015). A report by the United Nations Conference on Trade and Development (UNCTAD, 2016) suggests that some developing countries are losing up to $67 \%$ of the value of the raw materials they export owing to fraudulent international trade invoicing.

Reducing the tax losses occasioned by misinvoicing in international trade in raw materials represents a major challenge for developing countries. As noted by the Organization for Economic Cooperation and Development (OECD, 2015), there are large data gaps with regard to price-setting in the mining sector, and this makes it difficult for tax authorities to flag atypical transactions and check whether the quoted prices are fraudulent. This situation is compounded by the lack of international taxation expertise in the tax administrations of many developing countries (Readhead, 2016).

An analysis of the situation in specific cases in Latin America may therefore be of considerable interest. This study seeks to analyse the extent to which Chilean and Peruvian exports of copper products - copper concentrates and refined copper cathodes - are underinvoiced. Both of these countries play a significant role in the production and trade of these products globally, although the differences in the composition of their exports may influence the extent of underinvoicing in each country. According to the Chilean Copper Commission (COCHILCO, 2016), 44.8\% of Chilean exports of fine copper, by volume, are refined products, versus $17.6 \%$ in the case of Peru. Conversely, copper concentrates represent $47.3 \%$ of copper exports from Chile and $82.0 \%$ from Peru. ${ }^{2}$ In addition, copper-related economic activity is an important source of value added, investment, foreign exchange and public revenue in both countries. Accordingly, any trade misinvoicing could have major economic impacts.

In order to look into the possible manipulation of international mining commodity prices, this study draws on the wealth of data provided by the customs declarations filed by exporters with the customs administrations of these two countries. These declarations include information on the companies involved in the transactions and the export values and volumes concerned. In addition, and particularly in the case of Chile, they also provide information on the composition of the products that are being exported. This makes it possible to cross-check information on transactions conducted at an atypical price by a given exporter against information from the annual reports of that exporter, which detail the contractual terms applying to those sales.

A methodology based on the one developed by Hong, Pak and Pak (2014) is used to gauge the extent of underinvoicing by comparing the implicit unit price of a given raw material export with the observed price on the international market. This study contributes to the literature by introducing a number of novel methodological improvements. First of all, the method used to calculate the price filter incorporates a model of the typical approach used to set the price of each product. In addition,

\footnotetext{
2 The remaining volume of fine copper exports in both countries corresponds to other smelting products, which represent $7.9 \%$ of the total in Chile and $0.4 \%$ in Peru.
} 
rather than simply taking $10 \%$ off the market price to set the price floor, the market price f.o.b. (free on board) is calculated by applying the cost of freight and insurance (c.i.f.) shown on the Chilean customs declarations to each product in both countries.

The results of this analysis confirm the existence of transactions in which the implicit unit price declared by the exporter differs substantially from the expected price based on the market price and the benchmark contract terms for each product. They also show, however, that the level of underinvoicing fell in both absolute and relative terms over the course of the study period. This may be attributable to the reinforcement of the two countries' international tax regulatory systems, since both Chile and Peru have refined their anti-evasion rules, particularly those applying to transfer pricing.

This study is structured as follows. Section II looks at how the copper industry is organized in Chile and Peru and how it is positioned globally. Section III offers a brief description of the main methodologies for estimating price manipulation in international trade. Section IV outlines the methodology used in this study and its findings with regard to trade in Chilean and Peruvian copper products. Section $V$ sets out a number of conclusions and observations.

\section{Copper production and marketing}

Primary copper production begins with the extraction of copper-bearing ore by means of open-pit mining, underground mining or leaching (see diagram 1). Copper ore is not usually exported, since most of it is gangue, which has no commercial value (OECD, 2015). Ore is processed in one of two ways, depending on whether it is oxide or sulphide ore. Hydrometallurgical processes are generally used to treat oxide ores, with leaching and electrowinning processes being used to extract the copper and produce refined copper cathodes. It is estimated that about $18 \%$ of global refined copper output is obtained by this method (ICSG, 2015).

Diagram 1

Copper and copper product processing

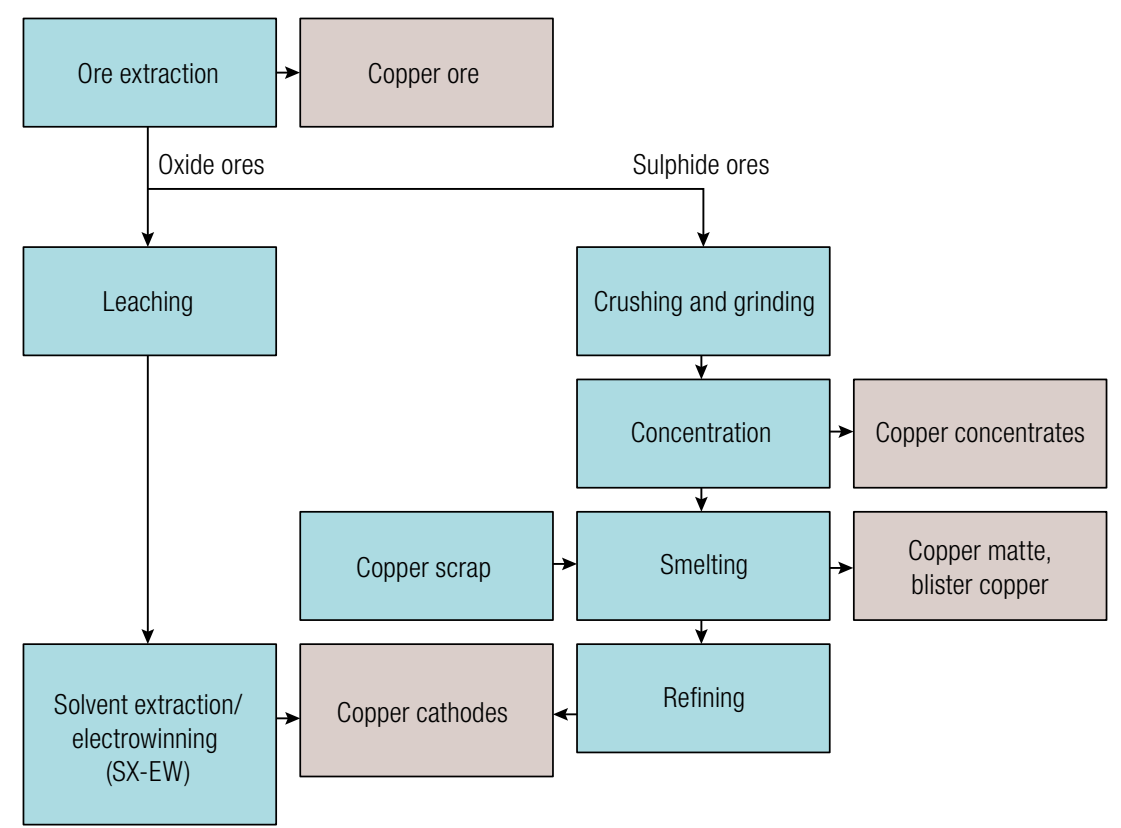

Source: Prepared by the authors, on the basis of Organization for Economic Cooperation and Development (OECD), "Addressing information gaps on prices of mineral products: mineral product pricing practices case studies: copper, gold and iron ore", Paris, 2015; and International Copper Study Group (ICSG), The World Copper Factbook 2014, Lisbon, 2015. 
Sulphide ores are crushed, ground and floated to obtain a concentrate with a copper content generally in the $20 \%-40 \%$ range, which is widely traded on the international market. The next stage is smelting, which produces copper matte (with a concentration of between $50 \%$ and $70 \%$ ) or blister copper (with a concentration of between 98.5\% and 99.5\%). According to OECD (2015), these products are not heavily traded on the international market. Finally, smelted copper is refined by electrolysis or firing to produce refined copper cathodes with a purity of $99.99 \%$ or more. The refined copper produced by these methods is extensively exported and accounts for around 64\% of world production (ICSG, 2015).

Scrap copper plays an important role in global copper production, as the secondary production of refined copper from recycled scrap accounts for about $18 \%$ of refined copper products worldwide (ICSG, 2015).

The available data can be used to analyse how copper production is distributed in Chile and Peru and how these countries' output stacks up against total production worldwide. According to statistics compiled by the United States Geological Survey (USGS), Chile is the world's largest copper producer, accounting for approximately $30 \%$ of global mining output as of 2015 . As shown in table 1 , of the 5.76 million metric tons (mt) of fine copper that Chile produced in that year, 3.99 million $\mathrm{mt}$ were copper concentrates and 1.78 million $\mathrm{mt}$ were refined cathodes produced by means of solvent extraction/electrowinning. Some of the concentrates were electrolytically refined to produce copper cathodes $(910,000 \mathrm{mt})$ and other smelted products. In all, $66 \%$ of the cathodes produced by Chile were refined by means of solvent extraction/electrowinning (SX-EW) and the other 34\% by electrolysis.

Table 1

Chile and Peru: fine copper production and exports, 2015

(Thousands of metric tons and percentages)

\begin{tabular}{|c|c|c|c|c|}
\hline \multirow{2}{*}{ Product } & \multicolumn{2}{|c|}{ Chile } & \multicolumn{2}{|c|}{ Peru } \\
\hline & Thousands of metric tons & Percentage of total & Thousands of metric tons & Percentage of total \\
\hline \multicolumn{5}{|c|}{ A. Production } \\
\hline Mine production of fine copper & 5764 & $\ldots$ & 1705 & $\ldots$ \\
\hline SX-EW cathodes (end product) & 1778 & 30.9 & 73 & 4.3 \\
\hline Concentrates & 3986 & 69.1 & 1632 & 95.7 \\
\hline Smelted products (end product) & 586 & 10.2 & 48 & 2.8 \\
\hline ER cathodes (end product) & 910 & 15.8 & 280 & 16.4 \\
\hline Concentrates (end product) & 2489 & 43.2 & 1304 & 76.5 \\
\hline Cathodes (SX-EW + ER): total & 2688 & 46.6 & 353 & 20.7 \\
\hline \multicolumn{5}{|c|}{ B. Exports } \\
\hline Exports of fine copper & 5737 & $\ldots$ & 1628 & $\ldots$ \\
\hline Concentrates & 2714 & 47.3 & 1335 & 82.0 \\
\hline Smelted products & 455 & 7.9 & 7 & 0.4 \\
\hline Cathodes & 2568 & 44.8 & 286 & 17.6 \\
\hline
\end{tabular}

Source: Prepared by the authors, on the basis of Chilean Copper Commission (COCHILCO), 1996-2015 Yearbook: Copper and other Mineral Statistics, Santiago, 2016; and Ministry of Energy and Mines, Anuario Minero, 2015, Lima, 2016.

Note: SX-EW: solvent extraction/electrowinning refining; ER: electrolytic refining.

Of Chile's 5.74 million $\mathrm{mt}$ of fine copper exports, 2.57 million $\mathrm{mt}$ ( $44.8 \%$ of the total) were refined cathodes, 2.72 million $\mathrm{mt}$ (47.3\%) were copper concentrates, and the rest (7.9\%) were other smelted products. ${ }^{3}$ Private companies accounted for most of the copper concentrate exports $(87.9 \%$ of the total in 2015), while the State-owned producer, CODELCO, was a distant second with just $12.1 \%$. This breakdown is also reflected in the composition of private enterprises' total exports, since copper concentrates represented $56.8 \%$ of their total international sales, whereas concentrates accounted for only $21.4 \%$ of the total exports of CODELCO.

3 Production volumes and export volumes for any given year may not match due to production lags. 
Peru was the world's third-largest copper producer in 2015, coming just slightly behind China. As shown in table 1, the country's fine copper mine output totalled 1.70 million mt (about $9 \%$ of the world total). The bulk of this was in the form of concentrates -1.63 million $\mathrm{mt}-$ as SX-EW cathodes amounted to only $73,000 \mathrm{mt}$ (which was still $20 \%$ of total cathode output). Some of the copper concentrates were used to produce electrolytically refined (ER) cathodes $(280,000 \mathrm{mt}$, or $80 \%$ of the total). The country's smelting and refining capacity is limited, which is why such a large percentage of its total production takes the form of concentrates $(76.5 \%$ in the case of Peru, versus $43.2 \%$ for Chile). In 2015 it exported 1.63 million mt of fine copper: 1.34 million $\mathrm{mt}$ of concentrates (82.0\%) and $286,000 \mathrm{mt}$ of cathodes (17.6\%).

Mining production is concentrated in a small group of companies in both of these countries. In Chile, the five largest producers accounted for 75\% of the country's total output in 2015 (COCHILCO, 2016), while, in Peru, the five biggest mining enterprises accounted for $81 \%$ of total production (Ministry of Energy and Mines, 2016). The fact that most of these firms are subsidiaries or joint ventures of multinationals is of particular importance for this study. In Chile, multinational corporations have a controlling interest in three of the five leading producers and, in Peru, they control all five of the biggest producers. ${ }^{4}$

Table 2 shows just how important a part Chile and Peru play in world trade in copper products. In 2015, these two countries exported 50\% of the world's total exports of copper ore and concentrates in terms of value. And Chile was by far the world's largest exporter of refined copper cathodes, with a market share of $34 \%$. Peru's ninth-place showing in this category, with a market share of just $4 \%$, is primarily a reflection of its limited smelting and refining capacity.

Table 2

Value of world exports of selected copper products and market shares of the main exporting countries, 2015

(Millions of dollars and percentages)

A. Copper ore and concentrates (HS6 260300)

\begin{tabular}{lcc}
\hline Country & Value & Market share \\
\hline Chile & 13891 & 34 \\
\hline Peru & 6568 & 16 \\
\hline Australia & 3659 & 9 \\
\hline United States & 3083 & 8 \\
\hline Canada & 3001 & 7 \\
\hline Mongolia & 2280 & 6 \\
\hline Brazil & 1984 & 5 \\
\hline Mexico & 1159 & 3 \\
\hline Spain & 1131 & 3 \\
\hline Philippines & 700 & 2 \\
\hline Other countries & 3237 & 8 \\
\hline Total & 40693 & 100 \\
\hline
\end{tabular}

B. Refined copper cathodes (HS6 740311)

\begin{tabular}{lcc}
\hline Country & Value & Market share \\
\hline Chile & 14357 & 34 \\
\hline Russian Federation & 3060 & 7 \\
\hline Japan & 2857 & 7 \\
\hline Australia & 2474 & 6 \\
\hline India & 1926 & 5 \\
\hline Poland & 1638 & 4 \\
\hline Republic of Korea & 1566 & 4 \\
\hline Kazakhstan & 1562 & 4 \\
\hline Peru & 1499 & 4 \\
\hline Canada & 1291 & 3 \\
\hline Other countries & 8663 & 21 \\
\hline Total & 40893 & 100 \\
\hline
\end{tabular}

Source: Prepared by the authors, on the basis of figures from the United Nations International Trade Statistics Database (COMTRADE).

These two countries' leadership positions in the international copper trade also have a major impact on their economies. In Chile, exports of copper products represented, on average, $47 \%$ of total exports in value terms between 2011 and 2015. In Peru, copper accounted for a smaller share of the total in this period, but it was still around $23 \%$. The difference between these two figures reflects

\footnotetext{
4 In Chile, the producers in which multinationals have a controlling interest are Minera Escondida (BHP Billiton is the majority shareholder), Compañía Minera Doña Inés de Collahuasi (a joint venture of Anglo American PLC, Glencore and Japan Collahuasi Resources B.V.) and Anglo American Sur (Anglo American PLC is the majority shareholder). In Peru, the multinational-controlled producers are Minera Antamina (jointly owned by BHP Billiton, Glencore, Teck and Mitsubishi Corporation), Southern Peru Copper Corporation (Grupo México S.A.B. de C.V.), Minera Cerro Verde (Freeport-McMoRan is the majority shareholder), Minera Antapaccay (Glencore) and Minera Chinalco Peru (Aluminum Corporation of China).
} 
the difference in these countries' production levels and Peru's more diversified production profile in the mining sector. Between 1995 and 2015, copper exports generated earnings of US\$ 418 billion for Chile and US\$ 96 billion for Peru. ${ }^{5}$

\section{Overview of methodologies for detecting price manipulation in international trade}

Historically, studies on price manipulation in international trade have employed the partner-country approach used by Bhagwati (1964 and 1974), which is based on the premise that country $A$ imports from country $B$ are also country $B$ exports to country $A$. If, after adjusting for the cost of insurance and freight (among other variables), the value of the imports recorded in a given country exceeds the value that the rest of the world has recorded as exports to that country, then imports have been overinvoiced. By the same token, if the adjusted value of the exports registered for a given country is lower that the values declared by other countries as imports to that country, then the exports have been underinvoiced.

A series of recent studies based on this approach have contributed to a new line of research that focuses on quantifying the extent of fraudulent misinvoicing in international trade (the overinvoicing of imports and the underinvoicing of exports) as a key component of illicit financial outflows from developing countries. Notable studies in this connection include the reports of Global Financial Integrity (Kar and Spanjers, 2015; Hollingshead, 2010), the Economic Commission for Africa (ECA, 2015) and the Economic Commission for Latin America and the Caribbean (ECLAC, 2016) on illicit financial flows connected with price manipulation in international trade.

An implicit assumption that is made with this method is that the values declared by a trading partner correspond to fully competitive pricing. The advantage is that it is not necessary to determine the price under full competition for each transaction (as must be done when using the price filter method), but this may distort the extent of intentional misinvoicing if the price declared by the partner country is not a free-market price either. Estimates arrived at using this approach reflect only those capital outflows for which one of the trading partners declares a price, amount or quality for the goods in question that differs from the price, amount or quality registered by the other partner. The possibility exists, however, that in some cases both the exporter and importer may record the same relative price for a product but one which is very different from its market price.

Another reason why this method may yield underestimates is that the data are aggregated by country, trading partner or product. The problem here is that each pair of trading-partner records will include a number of operations that may offset each other, since some of the trades may be overinvoiced and others underinvoiced. Another difficulty has to do with the asymmetry of bilateral trade statistics in any of a number of areas, such as differences in the valuation of imports and exports (c.i.f. and f.o.b.), differences in product classifications or nomenclatures, and differences in the attribution to trading partners and/or in re-export records (Javorsek, 2016).

The price filter methodology espoused by Zdanowicz, Pak and Sullivan (1999) and by Pak, Zanakis and Zdanowicz (2003) is aimed at detecting international trade transactions that diverge from what is considered to be a normal price range (i.e. market price or freely competitive price) and then gauging the extent of that divergence. The normal price range can be determined on the basis of either an analysis of the interquartile range or the free market price.

In the first of these approaches, the import and export declarations submitted to customs authorities are used to identify abnormal prices. The implicit prices of the highest and lowest quartile are calculated for each product category, and the prices in the range between these two points are

\footnotetext{
5 Figures from the United Nations International Trade Statistics Database (COMTRADE).
} 
considered to be fully competitive prices. Price manipulation is detected by comparing each entry in the trade database with the interquartile range for the corresponding product classification. If the declared price falls within that range, then the transaction is regarded as having taken place under full competition and is thus classified as a normal transaction. If the price is higher than the price of the highest quartile, it is regarded as signalling an instance of overinvoicing, and if it is below the value for the lowest quartile, it is regarded as a case of underinvoicing.

A number of shortcomings and limitations of this method have been pointed out in the literature, however. One of these has to do with its endogeneity, since the quartile price points are estimated on the basis of all commercial transactions, which will invariably include some operations conducted at prices below the lowest quartile price and some at prices above the highest quartile price, even if all the trades have been conducted under full competition. Interquartile price filters are also influenced by related-party transactions that are entered into the trade database. Thus, if there is a large number of this type of transaction, the estimated price range may not be representative of competitive prices.

Another problem arises when dealing with very heterogeneous products, since this method may lead to the mistaken classification of legitimate transactions of high-quality products as instances of overinvoicing, legitimate transactions of low-quality products as cases of underinvoicing and transactions of mid-range products conducted at abnormal prices as legitimate trades. In addition, in the case of products whose prices are very volatile, if the interquartile price range is estimated from annual data rather than taking monthly price variations into account, the estimates will be less accurate.

As also occurs with the partner-country method, another difficulty arises when the records are grouped for a given product category rather than using separate records for each shipment that is cleared through customs, since the aggregated data may include overinvoiced and underinvoiced transactions that offset one another, in which case the extent of price manipulation will be underestimated. Misinvoicing may also be underestimated when dealing with large-volume trades of a product if the price is marginally different from the free competition price. In such situations, since the price used in the transaction falls within the interquartile range, it will be classified as normal even though the total value being misinvoiced may be very high.

With the price filter method based on market prices, on the other hand, over- or underinvoicing is detected by comparing the implicit unit prices from customs records with a price (or price range) that is considered to have been determined on the basis of free competition and that has been posted by various markets or institutions. When the import or export price diverges from the free market price, then the transaction is considered to be based on a fraudulent price level.

For most products, it is extremely difficult to determine the true market price (the arm's length price or free competition price). There are some raw materials, however, for which the market is liquid and transparent enough to make it possible to identify the free market price. ${ }^{6}$

According to Hong, Pak and Pak (2014), the free-market price filter method has some advantages. One of these is the fact that it is not necessary to estimate the free competition price because the free market price published by various institutions can be used instead. In addition, unlike the interquartile price filter, the free market price filter incorporates monthly variations in product prices and is separate from declared import values, so related-party trades do not skew the estimates. However, free market prices are not available for all products and, even in the cases of commodity markets where prices are easily identifiable, those prices may not be representative of the final price obtained by the exporter because of the terms of reference contained in the contracts used by each industry. This was true of the estimates calculated for this study, where, in addition to the international price for the good in question, standard contract terms and conditions were also taken into account.

\footnotetext{
6 See, for example, Hong, Pak and Pak (2014), who calculated the extent of misinvoicing in trade in bananas by comparing the free market price with the price shown in United States import documentation.
} 


\section{Estimation of the extent of misinvoicing in international trade in Chilean and Peruvian copper products}

\section{Methodology}

The price filter methodology used by Hong, Pak and Pak (2014) and by Grondona and Burgos (2015) is used here to estimate the amount by which copper product exports may be underinvoiced. Unlike most of the studies that have been based on interquartile price filters, these authors compared the unit price of operations involving a specific product - bananas, in the first study, and soya products in the second - with the reference price for that product on the world market. This method is similar to the ones used to calculate transfer prices for related-party transactions, such as the so-called "sixth method" of transfer pricing valuation or a variant of the comparable uncontrolled price method. The contribution to the literature made by the research described here lies in the fact that, unlike the above studies, two adjustments were made that increase the estimates' accuracy. First, a pricing model was used that takes into account the contractual terms and conditions that the industry applies to copper products. Second, the calculation of the monthly market price f.o.b. incorporated the cost of insurance and freight as stated on customs declarations rather than assuming a flat 10\% reduction.

The main data sources were the customs declarations for exports of copper products from Chile and Peru and the market prices for copper, gold and silver. The information on external sales of mining products was obtained from the Penta-Transaction database, which contains the customs declarations filed by the exporters that are registered with the customs authorities. These declarations generally include the name of the exporter, the shipment date, the f.o.b. value and the gross and net weights of the export. In the case of Chile, they also include information on the composition of the products and the cost of insurance and freight (i.e. the c.i.f. value).

Market prices have been taken from the database maintained by the United Nations Conference on Trade and Development (UNCTAD), which gives monthly values for the main commodity exports. For the most part, these prices are given in c.i.f. terms, represent the agreed prices on major markets (such as the London Metal Exchange) and are for a given product description. For example, in the case of copper, the quoted price is for refined copper cathodes with a minimum grade of $99.99 \%$ (grade A).

The price filter for exports of copper ore and copper concentrates was based on the market price and the typical contractual terms and conditions applying to sales of these products on the international market. As explained by Teck (2015) and Nyrstar (2016), contracts governing the sale of copper concentrates generally set out the standard terms established annually by the leading mining and smelting enterprises. The price obtained by the mining company is set using the following equations.

First, the price of the metal contained in the concentrate is calculated:

$$
\text { Price of the metal }=\left((M \star D) \star P_{m}\right)+\left(\left(O_{m}{ }^{\star} D_{O m}\right) \star P_{O m}\right),
$$

where $M$ refers to the grade of the metal in the concentrate (usually between 20\% and 30\% for copper concentrates); $D$ stands for the percentage of the value of the metal paid after applying a standard deduction that covers the metal lost during smelting (mining companies typically receive between $96.5 \%$ and $96.75 \%$ of the metal's value); and $P_{m}$ stands for the going price of copper on the market. The contracts usually also provide for payment for the gold or silver content if the concentration of these metals exceeds a set threshold. In those cases, $O_{m}$ stands for the other metal (gold or silver) contained 
in the concentrate; $D_{O m}$ refers to the percentage of that metal that is paid for (around $90 \%$ ); and $P_{O m}$ stands for the market price of the metal.

Next, the deductions made for the processing of the concentrate are calculated:

$$
\text { Deductions }=T C R C+P P+R C_{O m}+\text { Other }
$$

$T C R C$ stands for the basic treatment charge and the refinery charge ( $T C$ and $\mathrm{RC}$, respectively), which, in theory, represent the cost of converting the concentrate into refined metal. $P P$ stands for the smelter's participation in the movement of the market price in the form of escalators and de-escalators. That share is calculated on a monthly basis as a set amount per ton which is then added to the per-dollar treatment charge if the market price is above the base price. On the other hand, if the market price is below the base price, then a fixed amount per ton is deducted from the treatment charge. (Since 2005-2006, however, the leading mining enterprises have not agreed to include this component in the reference contracts.) $R C_{O m}$ stands for the refinery charge for the non-copper metal (silver or gold) content of the concentrate. The "other" entry includes charges such as penalties for overly high levels of contaminants in the concentrate, but since precise information on the level of contaminants is not available, this component could not be included in the analysis.

The net market price c.i.f. is then calculated as the price of the metal in the concentrate minus the deductions provided for in the contract:

$$
\text { Net market price }=\text { price of the metal content }- \text { deductions }
$$

Next, the underinvoiced amount in trade in copper concentrates is estimated using the following equation:

$$
\text { Underinvoiced amount }=\text { volume } \star M A X\left(0, P_{*}-P\right)
$$

In this case, $P$ is the implicit unit price obtained from the customs declaration based on the concentrate's weight, net of its moisture content. ${ }^{7} P_{*}$ is equal to the net market price (obtained using equation (3)), expressed in dry metric tons less the cost of freight and insurance. These costs are calculated on a monthly basis from the Chilean customs declarations, which include information on the exports' c.i.f. value. The same values are used for Peru on the assumption that the prices are similar for the two countries.

Unfortunately, not all the customs declarations include detailed information on the composition of the export product. This occurs mainly in the case of Peru and makes the calculations more difficult to perform, since mining companies are paid based on the product's metal content. For both countries, three price filters corresponding to different grades are therefore used in order to cover the values usually employed in the industry. In Chile's case, since the customs declarations provide more information, an estimate is also given that takes the stated composition into account.

For refined copper cathode exports, the underinvoiced amount is calculated using an equation similar to the one proposed by Hong, Pak and Pak (2014), since the composition of the export product is assumed to be close to the composition used as a basis for the international reference price. In a departure from the approach used by those authors, however, the monthly market price is estimated in f.o.b. terms using the cost of insurance and freight reported on the Chilean customs declarations. These same values are then used for Peru as well.

\footnotetext{
7 In both countries, if the net weight was equal to the gross weight, the recorded weight was adjusted downward by $10 \%$ to arrive at an estimate of the weight in terms of dry metric tons.
} 


\section{Findings regarding copper ore and concentrates}

As shown in figure 1, the three price filters correlate with the movements in the implicit unit prices obtained from customs declarations. This indicates that most copper concentrate sales are made on the basis of the benchmark reference terms used by the industry. In the period between 2006 and the first half of 2016, the 7,872 customs declarations submitted in Chile corresponded to 72.10 million net metric tons having an f.o.b. value of US\$ 140.273 billion. In Peru, the 9,142 customs declarations submitted during that period corresponded to 35.11 million net metric tons having an f.o.b. value of US\$ 61.9 million. The implicit unit prices obtained from the declarations are US\$1.95/kg for Chile and US\$1.76/kg for Peru.

Figure 1

Chile and Peru: implicit unit prices obtained from customs declarations for exports of copper ore and concentrates (HS6 260300) and three different price filters, 2006-2016

(Dollars per net metric ton)

A. Chile

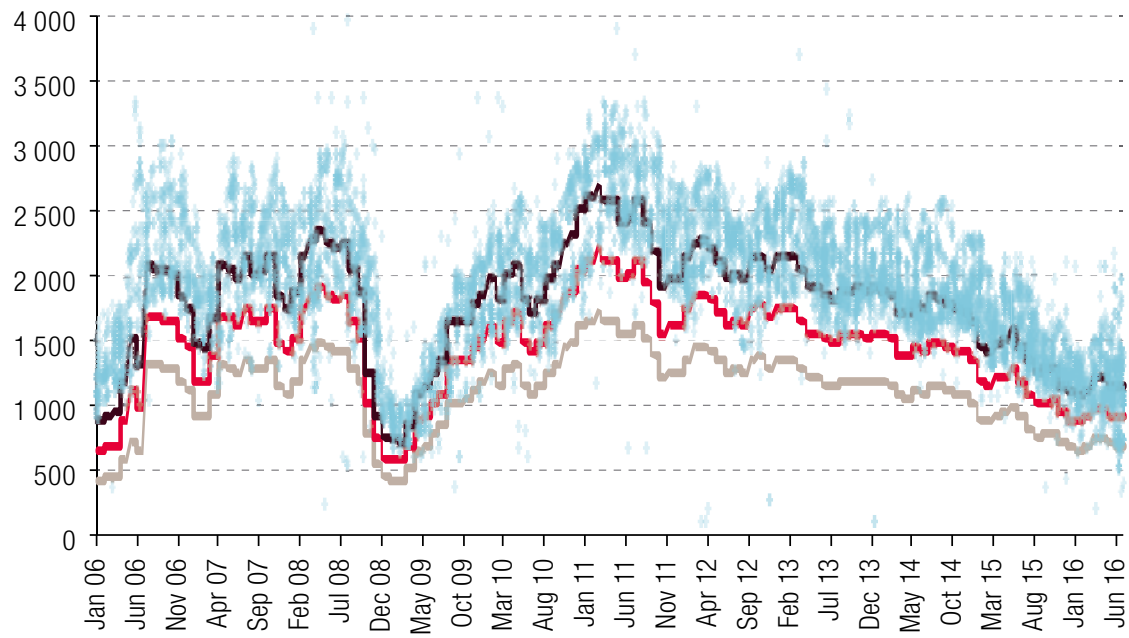

B. Peru

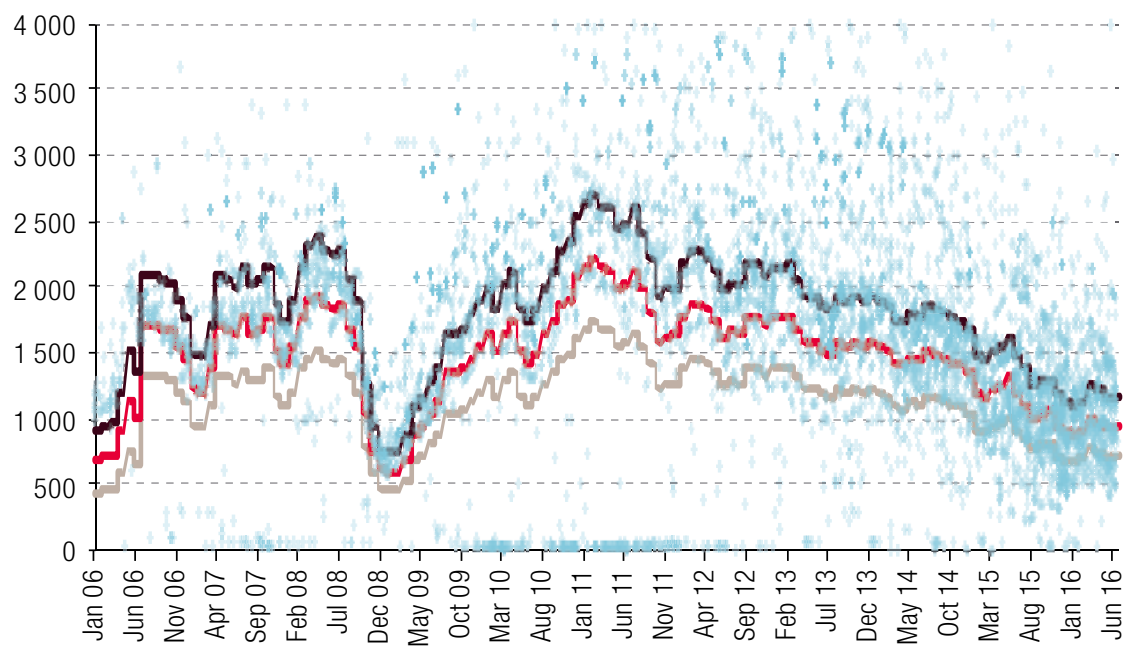

+ Observed prices _ Price filter (grade of 20\%)

- Price filter (grade of 25\%) Price filter (grade of $30 \%$ )

Source: Prepared by the authors, on the basis of figures from Penta-Transaction.

a As of the first half of 2016. 
Some transactions take place at price points above - and even, in some cases, far above - the upper bounds of the price filters. In such cases, it is highly likely that the exported concentrate contains an amount of silver or gold that raises the product's unit price. (As noted earlier, the contracts governing the sale of copper concentrates typically provide for an additional payment for these metals if their concentration exceeds a specified level.) Although Peruvian customs declarations do not usually provide information on the composition of the exported good, most Chilean ones do, and that information indicates that the average silver and gold content of these concentrates is substantial (around 2 grams of gold per metric ton and approximately 98 grams of silver per metric ton).

The observations for the two countries differ significantly, however. In the case of Chile, observed prices tend to remain within a more or less stable range over time; most transactions take place at prices above the upper bounds of the price filters for all of the grades covered in this study, which points to a degree of product homogeneity in terms of copper and precious metal content. In contrast, the unit prices derived from Peruvian customs declarations cover a wide range, which points to a considerable degree of product heterogeneity. Moreover, in Peru's case, a significant number of transactions involve price points below the lower bounds of all the price filters.

In Peru, a number of transactions have been registered at unit prices close to US\$ 0 per ton. A review of these declarations indicates that the vast majority of them concern exports that are transported by truck to the Chilean border. Although the composition of the products is not specified in the customs declarations, it is very probable that these products are copper ore rather than copper concentrate. In that case, the expected value of the products would be far below the lower bound of the price filter and thus would not necessarily be an instance of price manipulation. The volumes involved in these transactions are relatively small, especially in the case of shipments bound for China, and the part they play in the estimates of underinvoicing is therefore virtually nil.

The exports conducted by Peru in 2015-2016 are worthy of closer examination, particularly in the case of the customs declarations of Minera Chinalco Peru S. A., which began to export copper concentrates from its new Toromocho mine in 2014. These declarations give unit values below the lower bound of the price filter for copper with a grade of $20 \%$. Although the copper concentration of the product is not stated on most of these customs declarations, the few that do specify it indicate that the concentrates generally have a grade of between $20 \%$ and $22 \%$. However, the copper-bearing ore from this new mine contains excessive amounts of arsenic (CHINALCO-CMC, 2016), and the concentrates may therefore be bringing a lower price on the market. Consequently, the company may be selling these concentrates for less and, in that case, the transactions would not necessarily be reflecting price manipulation. The lack of the necessary information makes it unfeasible to adjust the estimates, however.

Table 3 gives the estimated amounts of copper concentrate exports from Chile and Peru that have been underinvoiced. In the case of Chile, the estimated value of underinvoiced exports amounted to US\$ 3.035 billion during the study period, which was equivalent to an estimated $2.2 \%$ of the total f.o.b. value of its exports of copper concentrates based on the composition of the concentrates as stated in the declarations (the "registered" entry). Most of this corresponds to the years between 2006 and 2010, when the underinvoiced value represented, on average, $4.0 \%$ of the total value of these exports. The amount of underinvoicing fell thereafter in both absolute and relative terms, accounting for an average of $0.9 \%$ of the value of exports in the years between 2011 and 2015.

In the case of Peru, using the intermediate $25 \%$-grade price filter, the underinvoiced value amounts to US\$1.083 billion in 2006-2016, or $1.8 \%$ of the f.o.b. value of these exports. The underinvoiced amounts trend upward and spike in 2015 in both absolute and relative terms, due in part to the exports from the new mine mentioned earlier (for which underinvoicing totalled US\$96.3 million in 2015). However, of the total amount of underinvoicing for the study period, around half (US\$ 538 million) corresponds to sales which may have involved concentrates with a copper content of less than $25 \%$, since mining operations 
in Peru are reportedly yielding concentrations of copper of between $20 \%$ and $30 \%$. Unfortunately, this supposition cannot be confirmed based solely on the information provided by customs declarations. If, nevertheless, the $20 \%$-grade price filter is applied instead, then this firm's level of underinvoicing during the study period is close to zero.

Table 3

Chile and Peru: f.o.b. values and underinvoiced amounts of exports of copper concentrates (HS6 260300) based on three price filters, 2006-2016

(Millions of dollars and percentages)

A. Chile

\begin{tabular}{|c|c|c|c|c|c|c|c|c|c|c|c|c|}
\hline & 2006 & 2007 & 2008 & 2009 & 2010 & 2011 & 2012 & 2013 & 2014 & 2015 & 2016 & Total \\
\hline \multicolumn{13}{|c|}{ Millions of dollars } \\
\hline $20 \%$ grade & 0 & 0 & 0 & 0 & 0 & 0 & 0 & 0 & 0 & 0 & 0 & 0 \\
\hline $25 \%$ grade & 7 & 53 & 62 & 106 & 104 & 33 & 49 & 6 & 4 & 17 & 61 & 504 \\
\hline $30 \%$ grade & 157 & 326 & 496 & 522 & 746 & 271 & 560 & 305 & 285 & 229 & 331 & 4229 \\
\hline Registered & 389 & 553 & 549 & 383 & 401 & 111 & 254 & 85 & 137 & 74 & 98 & 3035 \\
\hline f.o.b. value & 11376 & 13476 & 12866 & 7629 & 12375 & 14462 & 15912 & 17190 & 16475 & 12949 & 5564 & 140273 \\
\hline \multicolumn{13}{|c|}{ Percentages of f.o.b. value of exports } \\
\hline $20 \%$ grade & 0.0 & 0.0 & 0.0 & 0.0 & 0.0 & 0.0 & 0.0 & 0.0 & 0.0 & 0.0 & 0.0 & 0.0 \\
\hline $25 \%$ grade & 0.1 & 0.4 & 0.5 & 1.4 & 0.8 & 0.2 & 0.3 & 0.0 & 0.0 & 0.1 & 1.1 & 0.4 \\
\hline $30 \%$ grade & 1.4 & 2.4 & 3.9 & 6.8 & 6.0 & 1.9 & 3.5 & 1.8 & 1.7 & 1.8 & 5.9 & 3.0 \\
\hline Registered & 3.4 & 4.1 & 4.3 & 5.0 & 3.2 & 0.8 & 1.6 & 0.5 & 0.8 & 0.6 & 1.8 & 2.2 \\
\hline
\end{tabular}

\section{B. Peru}

\begin{tabular}{lrrrrrrrrrrrr}
\hline & 2006 & 2007 & 2008 & 2009 & 2010 & 2011 & 2012 & 2013 & 2014 & 2015 & 2016 & Total \\
\hline & & \multicolumn{7}{c}{ Millions of dollars } \\
\hline $20 \%$ grade & 1 & 4 & 11 & 1 & 6 & 7 & 5 & 12 & 11 & 35 & 24 & 118 \\
\hline $25 \%$ grade & 25 & 38 & 63 & 36 & 100 & 98 & 123 & 99 & 113 & 263 & 124 & 1083 \\
\hline $30 \%$ grade & 278 & 518 & 523 & 311 & 590 & 582 & 683 & 536 & 601 & 848 & 467 & 5936 \\
\hline f.o.b. value & 2794 & 4348 & 4666 & 3842 & 6248 & 7814 & 8044 & 7112 & 6934 & 6570 & 3535 & 61906 \\
\hline & & \multicolumn{8}{c}{ Percentages of f.o.b. value of exports } \\
\hline $20 \%$ grade & 0.0 & 0.1 & 0.2 & 0.0 & 0.1 & 0.1 & 0.1 & 0.2 & 0.2 & 0.5 & 0.7 & 0.2 \\
\hline $25 \%$ grade & 0.9 & 0.9 & 1.4 & 0.9 & 1.6 & 1.3 & 1.5 & 1.4 & 1.6 & 4.0 & 3.5 & 1.8 \\
\hline $30 \%$ grade & 9.9 & 11.9 & 11.2 & 8.1 & 9.4 & 7.5 & 8.5 & 7.5 & 8.7 & 12.9 & 13.2 & 9.6 \\
\hline
\end{tabular}

Source: Prepared by the authors, on the basis of figures from Penta-Transaction.

a As of the first half of 2016.

As is to be expected, the amount of underinvoicing is greatest in trade with the largest buyers of copper concentrates from these two countries (see table 4). Chile's exports to its five biggest trading partners represent nearly $85 \%$ of its total exports of this product, and these countries account for $78.2 \%$ of the estimated underinvoicing. In most of these cases, the percentage of underinvoicing was quite similar, ranging from $1.9 \%$ to $2.1 \%$; the exceptions were the Republic of Korea (1.4\%) and India (2.5\%).

In the case of Peru, using the $25 \%$-grade price filter, the country's five main trading partners accounted for $77.2 \%$ of the underinvoiced value and $76.5 \%$ of the total value of these exports. However, the figures for the individual countries vary quite a bit. The relative level of underinvoicing is the highest for Japan (3.2\%) and the Republic of Korea (2.5\%), in a middling range (1.6\% and $1.4 \%$ of the corresponding f.o.b. values, respectively) for Chile ${ }^{8}$ and for China (the biggest buyer) and very low for Germany (0.3\%).

\footnotetext{
8 Because Peru's copper smelting and refining capacity limited, a portion of its output of copper ore and copper concentrates is exported to Chile and refined there.
} 
Table 4

Chile and Peru: underinvoicing of exports of copper concentrates (HS6 260300), by trading partner, 2006-2016a

(Millions of dollars and percentages)

A. Chile (registered values)

\begin{tabular}{lccc}
\hline Country & $\begin{array}{c}\text { Amount } \\
\text { underinvoiced }\end{array}$ & f.o.b. value & $\begin{array}{c}\text { Percentage } \\
\text { of f.o.b. value } \\
\text { underinvoiced }\end{array}$ \\
\hline Japan & 821 & 41713 & 2.0 \\
\hline China & 767 & 39764 & 1.9 \\
\hline India & 456 & 18087 & 2.5 \\
\hline Republic of Korea & 165 & 11613 & 1.4 \\
\hline Brazil & 163 & 7940 & 2.1 \\
\hline Other countries & 661 & 21156 & 3.1 \\
\hline Total & 3035 & 140273 & 2.2 \\
\hline
\end{tabular}

B. Peru (25\%-grade price filter)

\begin{tabular}{lccc}
\hline Country & $\begin{array}{c}\text { Amount } \\
\text { underinvoiced }\end{array}$ & f.o.b. value & $\begin{array}{c}\text { Percentage } \\
\text { of f.o.b. value } \\
\text { underinvoiced }\end{array}$ \\
\hline China & 358 & 25020 & 1.4 \\
\hline Japan & 332 & 10329 & 3.2 \\
\hline Germany & 20 & 5991 & 0.3 \\
\hline Republic of Korea & 82 & 3291 & 2.5 \\
\hline Chile & 45 & 2726 & 1.6 \\
\hline Other countries & 247 & 14549 & 1.7 \\
\hline Total & 1083 & 61906 & 1.8 \\
\hline
\end{tabular}

Source: Prepared by the authors, on the basis of figures from Penta-Transaction.

a As of the first half of 2016.

\section{Findings regarding refined copper cathodes}

As shown in figure 2, most of the observed prices obtained from customs declarations for exports of refined copper cathodes from Chile and Peru are in line with the price filter. Between 2006 and the first half of 2016, a total of 83,767 customs declarations for refined copper exports were filed in Chile and 12,172 were filed in Peru. The value of Chile's 29.29 million metric tons of exports totalled US\$ 199.585 billion, while the value of Peru's 3.32 million metric tons of exports amounted to US\$22.713 billion. On average, the implicit unit price was US\$ 6.8/kg for both countries.

Some of each country's export transactions were atypical, however, as they diverged from the market price trend. In the case of Chile, there is a long series of transactions spanning the entire period that run in nearly a straight line situated substantially below the market price. A closer inspection shows that these trades are sales made by CODELCO to Chinese buyers. This is accounted for by the fact that, in May 2005, CODELCO signed a contract with China Minmetals Corporation for the sale of 836,250 tons of cathodes over a period of 15 years (180 months). The contract stipulated that the sale price would be computed on the basis of one fixed readjustable component plus a variable component that would be determined in line with the market price at the time of shipment. Exports under this contract began in June 2006 and were channelled through Copper Partners Investment Company Ltd. of Bermuda, with CODELCO and that company holding equal equity interests. In 2016, CODELCO withdrew from that joint venture and terminated its contract with Minmetals after Chile's tax authorities questioned the joint venture's tax structure and ordered CODELCO to pay US\$149 million in back taxes in 2015 (CODELCO, 2016).

For Peru, especially at the beginning of the study period, transactions are noted in which the observed price remains below the market price for several months at a time (see figure 2). Between January and November 2006, the observed prices for one group of operations, in particular, trended steeply downward. These trades involved sales of copper cathodes by a subsidiary of a United States firm to customers in that country. Unfortunately, the customs declarations do not provide information on the buyer, so it cannot be determined whether these were related-party sales or not. What is striking about these trades is that the unit prices trended downward while the market price was rising sharply (by $61 \%$ between January and May 2006). 
Figure 2

Chile and Peru: implicit unit prices derived from customs declarations for exports of refined copper (HS6 740311) and the corresponding price filter, 2006-2016a

(Dollars per net $\mathrm{kg}$ )

A. Chile

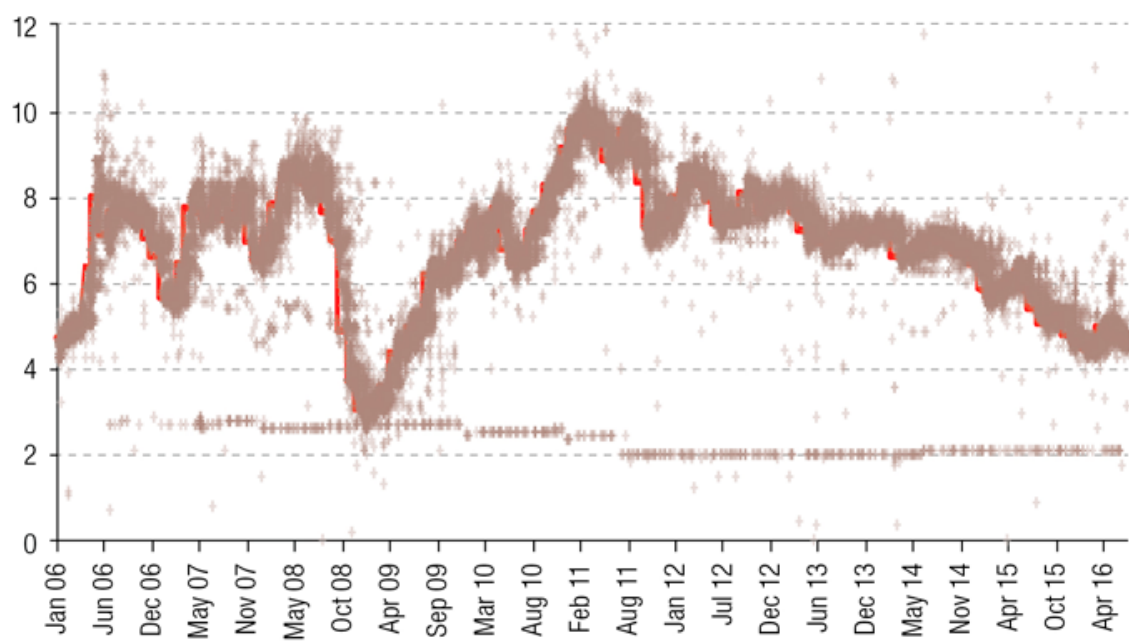

B. Peru

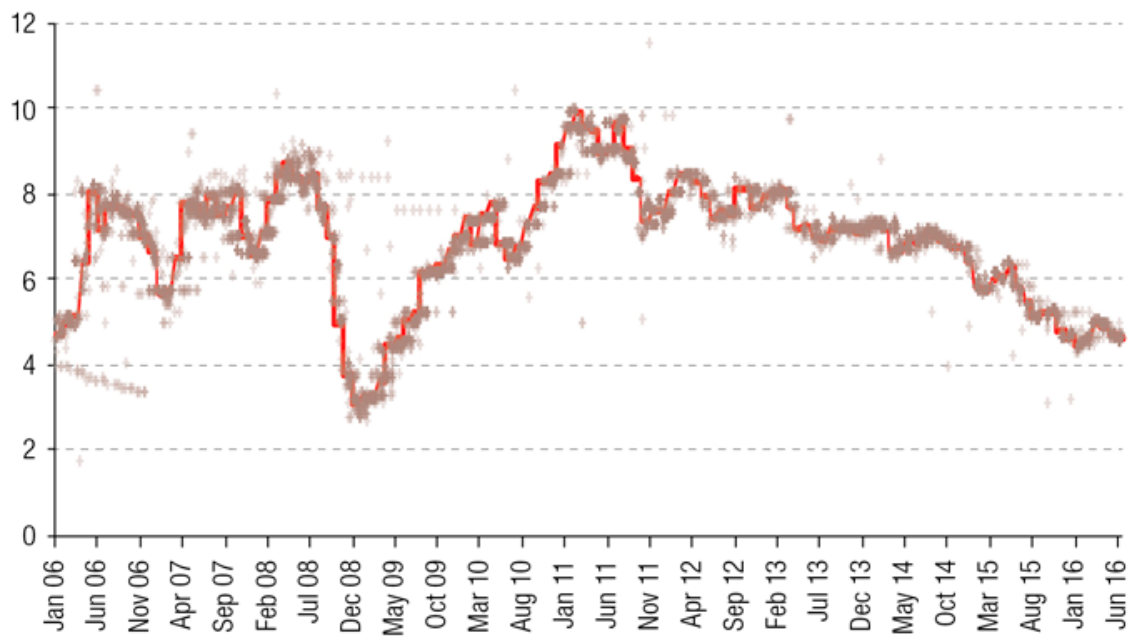

+ Observed prices $\quad-$ Price filter

Source: Prepared by the authors, on the basis of figures from Penta-Transaction.

a As of the first half of 2016.

In contrast, most of the other atypical clusters of transactions were conducted at a set price, i.e. they follow a horizontal line on the graph. For example, in 2007, some of the exports from Southern Peru Copper Corporation were made at similar prices throughout the year even though the market price was quite unstable during that period. In this case, the firm's audit report for that year states that the company used to sell copper on the basis of annual contracts, which could explain why sales during the same year were made at the same price (Southern Peru Copper Corporation, 2008).

Table 5 shows the underinvoiced amounts, by value, of exports of refined copper cathodes from Chile and Peru. For Chile, they are estimated at US\$ 6.348 billion between 2006 and the first half of 2016 , or $3.2 \%$ of the total value of those exports. Of that amount, US $\$ 2.516$ billion (40\%) corresponds 
to transactions governed by the long-term contract concluded by CODELCO and Minmetals. In the case of the rest of these transactions (US\$ 3.833 billion, or $1.9 \%$ of the total value of those exports), a definite downward trend is apparent, with the underinvoiced amounts dropping from an average of US\$ 567 million per year between 2006 and 2010 to an average of US\$ 182 million between 2011 and 2015. As a result, the share of the total export value that appears to have been underinvoiced fell from an average of $3.1 \%$ in 2006-2010 to $0.9 \%$ in 2011-2015. In the case of Peru, the underinvoiced amount totalled US\$ 369 million between 2006 and the first half of 2016, or 1.6\% of the total. As is also true of Chile, both the value of underinvoiced shipments and their relative size in terms of total export values declined considerably during the study period.

Table 5

Chile and Peru: underinvoiced amounts of exports of refined copper (HS6 740311), 2006-2016a (Millions of dollars and percentages)

A. Chile

\begin{tabular}{|c|c|c|c|c|c|c|c|c|c|c|c|c|}
\hline & 2006 & 2007 & 2008 & 2009 & 2010 & 2011 & 2012 & 2013 & 2014 & 2015 & 2016 & Total \\
\hline \multicolumn{13}{|c|}{ Millions of dollars } \\
\hline Refined copper & 564 & 862 & 767 & 771 & 935 & 645 & 628 & 424 & 334 & 291 & 127 & 6348 \\
\hline $\begin{array}{l}\text { CODELCO/ } \\
\text { Minmetals }\end{array}$ & 75 & 319 & 253 & 130 & 285 & 347 & 329 & 300 & 253 & 186 & 39 & 2516 \\
\hline Other & 489 & 543 & 514 & 642 & 651 & 298 & 299 & 124 & 81 & 105 & 88 & 3833 \\
\hline f.o.b. value & 16114 & 19544 & 20307 & 15054 & 22646 & 25727 & 22066 & 19655 & 17087 & 14651 & 6738 & 199590 \\
\hline \multicolumn{13}{|c|}{ Percentages of f.o.b. value of exports } \\
\hline Refined copper & 3.5 & 4.4 & 3.8 & 5.1 & 4.1 & 2.5 & 2.8 & 2.2 & 2.0 & 2.0 & 1.9 & 3.2 \\
\hline $\begin{array}{l}\text { CODELCO/ } \\
\text { Minmetals }\end{array}$ & 0.5 & 1.6 & 1.2 & 0.9 & 1.3 & 1.3 & 1.5 & 1.5 & 1.5 & 1.3 & 0.6 & 1.3 \\
\hline Other & 3.0 & 2.8 & 2.5 & 4.3 & 2.9 & 1.2 & 1.4 & 0.6 & 0.5 & 0.7 & 1.3 & 1.9 \\
\hline
\end{tabular}

\section{B. Peru}

\begin{tabular}{lrrrrrrrrrrrrr}
\hline & 2006 & 2007 & 2008 & 2009 & 2010 & 2011 & 2012 & 2013 & 2014 & 2015 & 2016 & Total \\
\hline & & & \multicolumn{7}{c}{ Millions of dollars } \\
\hline Refined copper & 73 & 48 & 49 & 54 & 71 & 33 & 22 & 6 & 3 & 7 & 2 & 369 \\
\hline f.o.b. value & 3005 & 2372 & 2571 & 1817 & 2495 & 2790 & 1846 & 1834 & 1838 & 1511 & 635 & 22713 \\
\hline & & & \multicolumn{8}{c}{ Percentages of f.o.b. value of exports } \\
\hline Refined copper & 2.4 & 2.0 & 1.9 & 3.0 & 2.8 & 1.2 & 1.2 & 0.3 & 0.2 & 0.5 & 0.2 & 1.6 \\
\hline
\end{tabular}

Source: Prepared by the authors, on the basis of figures from Penta-Transaction.

a As of the first half of 2016.

As in the case of trade in copper concentrates, the biggest buyers account for the bulk of the underinvoiced sales. Table 6 shows that, in Chile, the five leading trading partners account for $72.0 \%$ of the exported value and $82.2 \%$ of the underinvoiced value. Sales to China represented a majority of the underinvoiced amount (59.4\%), largely as a result of the terms of the contract concluded between CODELCO and Minmetals. Consequently, the underinvoicing of sales to China equalled $5.3 \%$ of the value of exports during the period in question. In contrast, the percentage of total exports, by f.o.b. value, that were underinvoiced and were not governed by that contract equalled $1.8 \%$, which is in line with the figures for other trading partners (ranging between $1.6 \%$ and $2.4 \%$ ).

Peru's five biggest trading partners accounted for $88.3 \%$ both of its exports of this product by value and of the underinvoiced portion of those exports. In absolute terms, its exports to the United States entailed the most underinvoicing during the study period (US\$108 million), and this was also true in relative terms (2.3\% of the f.o.b. value compared to between $0.9 \%$ and $1.8 \%$ for the country's other trading partners). The bulk (54\%) of the underinvoicing in sales to the United States occurred during the early years of the study period (2006 and 2007), which is in line with the observations made in connection with the data shown in figure 2. 
Table 6

Chile and Peru: underinvoicing of exports of refined copper (HS6 740311), by trading partner, 2006-2016

(Millions of dollars and percentages)

A. Chile

\begin{tabular}{lccc}
\hline Country & $\begin{array}{c}\text { Amount } \\
\text { underinvoiced }\end{array}$ & f.o.b. value & $\begin{array}{c}\text { Percentage } \\
\text { of f.o.b. value } \\
\text { underinvoiced }\end{array}$ \\
\hline China & 3768 & 71616 & 5.3 \\
\hline $\begin{array}{l}\text { excluding CODELCO/ } \\
\text { Minmetals }\end{array}$ & 1252 & 70350 & 1.8 \\
\hline $\begin{array}{l}\text { United States } \\
\text { Italy }\end{array}$ & 418 & 26174 & 1.6 \\
\hline Republic of Korea & 415 & 16993 & 2.4 \\
\hline $\begin{array}{l}\text { Taiwan Province } \\
\text { of China }\end{array}$ & 295 & 14807 & 2.0 \\
\hline Other countries & 1128 & 14065 & 2.3 \\
\hline Total & 6348 & 199590 & 3.2 \\
\hline
\end{tabular}

B. Peru

\begin{tabular}{lccc}
\hline Country & $\begin{array}{c}\text { Amount } \\
\text { underinvoiced }\end{array}$ & f.o.b. value & $\begin{array}{c}\text { Percentage } \\
\text { of f.o.b. value } \\
\text { underinvoiced }\end{array}$ \\
\hline China & 46 & 5251 & 0.9 \\
\hline Italy & 77 & 4873 & 1.6 \\
\hline United States & 108 & 4608 & 2.3 \\
\hline Brazil & 61 & 3306 & 1.8 \\
\hline $\begin{array}{l}\text { Taiwan Province } \\
\text { of China }\end{array}$ & 34 & 2015 & 1.7 \\
\hline Other countries & 43 & 2659 & 1.6 \\
\hline Total & 369 & 22713 & 1.6 \\
\hline & & &
\end{tabular}

Source: Prepared by the authors, on the basis of figures from Penta-Transaction.

a As of the first half of 2016.

\section{Conclusions}

The findings arrived at in this study using a new methodology that has been adapted to local conditions in Chile and Peru show that some exports of copper concentrates and refined copper have been conducted at below-market unit prices (with market prices being determined on the basis of the industry's typical contractual terms and the costs of insurance and freight). These operations warrant scrutiny on the part of the proper authorities in order to determine if they have involved fraudulent misinvoicing or not. This would pave the way for the type of oversight that would assist the authorities in designing and implementing measures for reducing the loss of tax revenues associated with such operations. An additional consideration has to do with the fact that, since the copper industry is such an important one for both Chile and Peru, a widespread public perception that tax revenues are being lost due to the actions of this industry could have serious repercussions in terms of public confidence in the tax system in these countries.

It is estimated that the potential value of exports of copper concentrates that may have been underinvoiced in the period between 2006 and the first half of 2016 totalled US\$ 3.035 billion in Chile (2.2\% of the value exported) and US\$ 1.083 billion (1.8\% of the value exported, assuming a grade of $25 \%$ ) in Peru. The potentially underinvoiced amounts in sales of refined copper cathodes were US\$ 3.833 billion in Chile (3.2\% of the value exported) and US\$ 369 million in Peru (1.6\% of the value exported). ${ }^{9}$

The level of underinvoicing decreased in both absolute and relative terms over the course of the study period. The amount of underinvoicing in the case of Chilean exports of copper concentrates dropped from an average of $4.0 \%$ of the total export value in $2006-2010$ to an average of $0.9 \%$ in

9 These are conservative estimates, since other ways of undervaluing exports on customs documentation may exist which have not been captured for lack of the necessary data. For example, a study conducted by the Journalism Research Centre (CIPER) of Chile found that, for decades, exports of copper concentrates from that country had not been inspected or checked, with the authorities simply accepting the information supplied by the mining companies on the concentrates' grade and weight at face value. Castillo (2015) also asserts that the patchy or faulty inspection of mining exports is the greatest failing of the customs administration of that country. In the same vein, an investigative committee of the Chamber of Deputies of Chile has concluded that the country lacks a suitable institutional structure for maintaining the type of effective, rigorous oversight needed to ensure product traceability in the copper industry. That committee stated that oversight agencies are underfunded and have not been given sufficient authority (Chamber of Deputies Chile, 2015). 
2011-2015. For those same subperiods, the underinvoicing of refined copper exports fell from an average of $3.1 \%$ in Chile and $2.4 \%$ in Peru to averages of $0.9 \%$ and $0.7 \%$, respectively. This may be attributable to the reinforcement of the two countries' international tax regulatory systems, since both Chile and Peru have refined their anti-evasion and anti-avoidance rules, particularly those applying to transfer pricing. Nevertheless, the progress made in this connection is only a first step towards building a strong enough institutional and legal framework to tightly police all the different stages involved in this activity, starting with mining operations themselves and continuing on to the sale of these products on the international market.

A number of difficulties were encountered when attempting to estimate the amount of these exports, by value, that has been underinvoiced. Although exporters' customs declarations were used as a data source because they make a much more detailed analysis possible, in most cases they still do not provide all the information needed to accurately calculate all the payments and deductions involved in each transaction. The financial reports of a number of the firms involved in undervalued transactions were also available, but they generally do not provide complete, detailed information on the terms and conditions of the contracts that these companies sign with their buyers. All of this serves to underscore the challenges faced by the relevant countries' tax and customs authorities in seeking to verify the sworn statements submitted by mining companies. This also points up the importance of having customs records that provide more detailed and complete information on the concentration, composition and characteristics of each product and on the buyers (especially the type of information needed to determine whether it is a related-party transaction or not) so that the authorities can keep a close watch over them.

Future work in this field should focus on identifying other ways in which mining firms illegally divert profits and send them abroad. Although the evidence suggests that an increasing percentage of the international copper trade is being conducted under market conditions, these producer countries could still be losing tax revenues as a result of other strategies, such as, in particular, transactions between subsidiaries - which play an important role in the mining sector in both of these countries - and their parent companies abroad. Even though related-party operations are governed by the rules on transfer pricing, they usually include payments for services whose market value is very difficult to ascertain. Mining companies' financial structures should therefore also be examined in order to determine whether they have been intentionally designed to artificially reduce those firms' tax obligations. The possible abuse of financial derivatives as a vehicle for transferring profits out of the region should also be investigated more thoroughly (PWYP Norway, 2011).

A promising development in this field is the deployment by the OECD/G-20 Base Erosion and Profit Shifting (BEPS) Project of a broad package of consensus-based measures for combating these types of practices. In particular, the BEPS provision for country-by-country reporting will provide tax authorities with an overall picture of the operations of multinational corporations, since these reports will state where these enterprises report their profits, taxes and economic activities. This information will enable tax authorities to assess the risks involved in transfer pricing and other BEPS practices so that they can focus their inspection and oversight resources on the most critical areas. 


\section{Bibliography}

Bhagwati, J. (1974), "Fiscal policies, the faking foreign trade declarations, and the balance of payments", Illegal Transactions in International Trade, J. N. Bhagwati (ed.), Amsterdam, North Holland.

(1964), "On the underinvoicing of imports", Bulletin of the Oxford University Institute of Economics and Statistics, vol. 26, No. 4 Oxford, University of Oxford.

Castillo, R. (2015), El cobre: anatomía del mayor fraude minero en Chile, Santiago, Andros Impresores.

Chamber of Deputies of Chile (2015), "Informe de la Comisión Especial Investigadora encargada de analizar las eventuales responsabilidades de CODELCO y de ENAMI, con ocasión de la sustracción de concentrados de cobre", 3 March [online] https://www.camara.cl/pdf.aspx?prmID=14119\&prmTIPO=INFORMECOMISION.

CHINALCO-CMC (CHINALCO Mining Corporation International) (2016), Annual Report, 2015 [online] http:// www.hkexnews.hk/listedco/listconews/sehk/2016/0428/LTN20160428325.pdf.

COCHILCO (Chilean Copper Commission) (2016), 1996-2015 Yearbook: Copper and other Mineral Statistics, Santiago.

CODELCO (Corporación Nacional del Cobre de Chile) (2016), Memoria Anual, 2015, Santiago.

ECA (Economic Commission for Africa) (2015), Illicit Financial Flow. Report of the High Level Panel on Illicit Financial Flows from Africa, Addis Ababa.

ECLAC (Economic Commission for Latin America and the Caribbean) (2016), Economic Survey of Latin America and the Caribbean, 2016 (LC/G.2684-P), Santiago.

Grondona, V. and M. Burgos (2015), "Estimación de los precios de transferencia: el caso del complejo sojero", Working Paper, No. 71, Buenos Aires, Center of Economics and Finance for the Development of Argentina (CEFID-AR).

Hollingshead, A. (2010), The Implied Tax Revenue Loss from Trade Mispricing, Washington, D.C., Global Financial Integrity.

Hong, K., C. Pak and S. Pak (2014), "Measuring abnormal pricing - an alternative approach: the case of US banana trade with Latin American and Caribbean countries", Journal of Money Laundering Control, vol. 17, No. 2, Bingley, Emerald.

ICSG (International Copper Study Group) (2015), The World Copper Factbook 2014, Lisbon.

Javorsek, M. (2016), "Asymmetries in international merchandise trade statistics: a case study of selected countries in Asia-Pacific", Working Paper Series, No. SD/WP/02, Bangkok, Economic and Social Commission for Asia and the Pacific (ESCAP) [online] http://www.unescap.org/sites/default/files/ SD_Working_Paper_April2016_Asymmetries_in_International_Trade_Statistics.pdf.

Kar, D. and J. Spanjers (2015), Illicit Financial Flows from Developing Countries: 2004-2013, Washington, D.C., Global Financial Integrity.

Ministry of Energy and Mines (2016), Anuario Minero, 2015, Lima.

Nyrstar (2016), "Modeling Nyrstar", August [online] http://www.nyrstar.com/investors/en/Investors\%20 Materials/English/Modeling\%20Nyrstar.pdf.

OECD (Organization for Economic Cooperation and Development) (2015), "Addressing information gaps on prices of mineral products: mineral product pricing practices case studies: copper, gold and iron ore", Paris.

Pak, S. J., S. H. Zanakis and S. J. Zdanowicz (2003), "Detecting abnormal pricing in international trade: the Greece-USA case", Interfaces, vol. 33, No. 2, Catonsville, INFORMS.

PWYP Norway (Publish What You Pay Norway) (2011), "Protection from derivative abuse", December [online] https://www.publishwhatyoupay.no/sites/all/files/1006a-PWYP_DerivativesReport_ENG_DOWNLOAD_0.pdf.

Readhead, A. (2016), Preventing Tax Base Erosion in Africa: a Regional Study of Transfer Pricing Challenges in the Mining Sector, Natural Resource Governance Institute.

Southern Peru Copper Corporation (2008), "Estados financieros, 31 de diciembre de 2007 y 31 de diciembre de 2006", Lima.

Teck (2015), "Modelling Workshop", November [online] http://www.teck.com/media/Investors-PresentationsWebcasts-20151104-modelling-workshop.pdf.

UNCTAD (United Nations Conference on Trade and Development) (2016), Trade Misinvoicing in Primary Commodities in Developing Countries: The Cases of Chile, Cote d'Ivoire, Nigeria, South Africa and Zambia (UNCTAD/SUC/2016/2), Geneva.

Zdanowicz, J., S. Pak and M. Sullivan (1999), "Brazil-United States trade: capital flight through abnormal pricing", The International Trade Journal, vol. 13, No. 4, Abingdon, Taylor \& Francis. 